\title{
Description of two new species of the tribe Chrysillini Simon, 1901 from India (Araneae: Salticidae)
}

\author{
Описание двух новых видов трибы Chrysillini Simon, 1901 \\ из Индии (Araneae: Salticidae)
}

\author{
Dhruv A. Prajapati1,", Somnath B. Kumbhar ${ }^{2}$, John T.D. Caleb ${ }^{3}$, \\ Rajesh V. Sanap ${ }^{4}$, Ravi D. Kamboj ${ }^{5}$ \\ Ахрув А. Праджапати 1,* Сомнат Б. Кумбхар², Ажкон Т.А. Калеб, \\ Раджеш В. Санап ${ }^{4}$, Рави А. Камбоджк

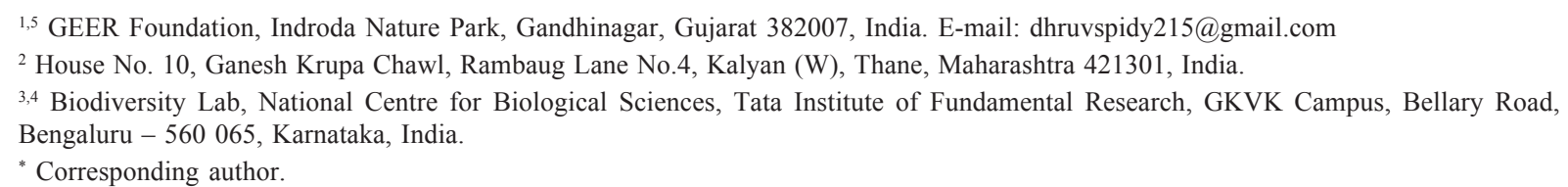

KEY WORDS: Aranei, Icius, jumping spiders, Phintella, taxonomy.

КЛЮЧЕВЫЕ СЛОВА: Aranei, Icius, пауки-скакунчики, Phintella, таксономия.

ABSTRACT. Two new species of the jumping spiders, Phintella cholkei sp.n. ( $\left.\sigma^{\top}+\right)$ and Icius tukarami sp.n. $\left(\sigma^{7}\right)$, from Maharashtra state, India are described. Their detailed morphological descriptions, diagnoses and illustrations of the copulatory organs are provided. Yet, observations on maternal care and habitat of $P$. cholkei sp.n. are provided as well.

How to cite this paper: Prajapati D.A., Kumbhar S.B., Caleb J.T.D., Sanap R.V., Kamboj R.D. 2021. Description of two new species of the tribe Chrysillini Simon, 1901 from India (Araneae: Salticidae) // Arthropoda Selecta. Vol.30. No.2. P.230-238. doi: 10.15298/arthsel.30.2.10

РЕЗЮМЕ. Описаны два новых вида пауков-скакунчиков, Phintella cholkei sp.n. ( $\left(\sigma^{7}\right.$ ) и Icius tukarami sp.n. $\left(\sigma^{7}\right)$, из штата Махараштра, Индия. Представлены их детальные морфологические описания, диагнозы и иллюстрации копулятивных органов. Дополнительно также приводятся наблюдения о материнской заботе и местообитании вида $P$. cholkei sp.n.

\section{Introduction}

Many salticids have been recently described from India [WSC, 2021], of which several species belong to the tribe Chrysillini. The Indian chrysilline diversity is represented by 45 species in 15 genera [Maddison, 2015; WSC, 2021]. The most abundant genus of this tribe is Phintella Strand, 1906, comprising 63 species in the world and 11 in the Indian fauna [Prószyński, 1978, 1984, 1992a,b; WSC, 2021; Żabka, 1988]. The genus Icius Simon, 1876 has only three Indian representatives, and all of them were described recently [Caleb, 2017; Prajapati et al., 2018; Prajapati, Kamboj, 2019; WSC, 2021].

The present paper is aimed to describe two new species of the genera Phintella and Icius from Maharashtra state of India.

\section{Materials and methods}

Specimens were hand-collected and studied using a Nikon SMZ25 stereozoom microscope. All measurements are in millimetres (mm). Palp and leg segment lengths are given as follows: total [femur, patella, tibia, metatarsus (except palp), tarsus]. Spination pattern and description standard follow Davis [1994] and Sebastian et al. [2015], respectively. Drawings were made with an aid of a drawing tube attached to the microscope. Digital images were obtained by a Nikon DSFi3 digital camera attached to Nikon SMZ25 stereozoom microscope enabled with the image analysis software NIS - Element D. All drawings and photos were edited and assembled using Adobe Photoshop CS5. The type specimens have been deposited in the reference collection of the Gujarat Ecological and Educational Research (GEER) Foundation, Gandhinagar, Gujarat and National Centre for Biological Sciences (NCBS), Bengaluru. The distribution map was prepared using the QGIS software, version 3.10.

Abbreviations used in the text and figure plates: ALE anterior lateral eye, AME - anterior median eye, CD copulatory duct, $\mathrm{CO}$ - copulatory opening, E - embolus, EP - epigynal pocket, FD - fertilization duct, PTE prolateral tegular extension, IRTA - inferior retrolateral tibial apophysis, PLE - posterior lateral eye, PME - posterior median eye, RL — retrolateral lobe of tegulum, RTA retrolateral tibial apophysis, SD - sperm duct, SRTA superior retrolateral tibial apophysis, I-IV -1 st to 4th legs. 


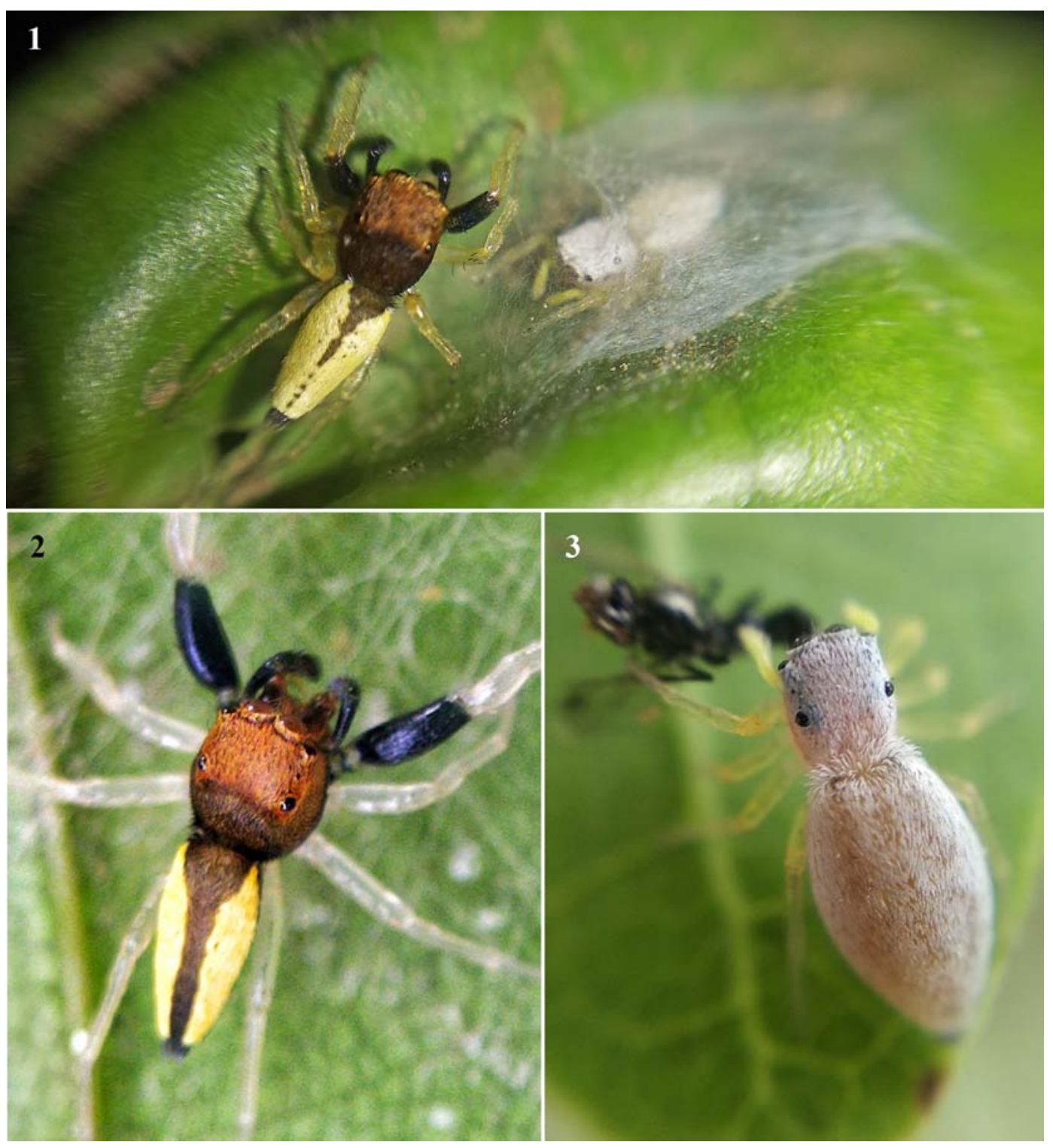

Figs 1-3. Live specimens of Phintella cholkei sp.n.: 1 - male (left) and female (right, in the retreat); 2 - male; 3 - female. Рис. 1-3. Живые экземпляры Phintella cholkei sp.n.: 1 - самец (слева) и самка (справа, в укрыти); 2 - самец; 3 - самка.

\section{Taxonomy}

Phintella Strand, 1906

Type species: Phintella bifurcilinea (Bösenberg et Strand, 1906).

DIAGNOSIS. Phintella can be easily distinguished from other chrysilline by the following characters: the short embolus situated at the top of the bulb, being complemented with the prolateral tegular extension; tegulum with a smaller retrolateral lobe or hump; RTA small to moderate in size (rarely large as in P. longapophysis Lei et Peng, 2013 and $P$. cholkei sp.n., see below), sometimes bifurcated; the simple epigyne, sometimes with a scapum or pockets; the spermathecae spherical; the copulatory ducts of various length, usually without twists. For detailed diagnostic characters of the genus see Żabka [2012].

\section{Phintella cholkei sp.n.}

Figs 1-25, Map 1.

TYPES. Holotype $\sigma^{7}$ (GEER, 971A), India, Maharashtra, Thane, Rambaug in Kalyan $\left(19^{\circ} 14^{\prime} 28.99^{\prime \prime} \mathrm{N}, 73^{\circ} 8^{\prime} 80.82^{\prime \prime} \mathrm{E}\right), 12 \mathrm{~m}$ a.s.1., hand-collected from foliage, 21.04.2019, S.B. Kumbhar. Paratypes: $1 O^{7}, 2$ 우 (GEER, 971B), together with the holotype; 1 $0^{7}, 1$ ㅇ (NCBS), Maharashtra, Mumbai, Aarey Milk Colony (19 $\left.8^{\prime} 33.08^{\prime \prime} \mathrm{N}, 72^{\circ} 52^{\prime} 2.99^{\prime \prime} \mathrm{E}\right), 37 \mathrm{~m}$ a.s.1, 17.11.2017, R.V. Sanap.

ETYMOLOGY. The specific epithet is a patronym in remembrance of the second author's friend, Mr Kamlesh Cholke.

DIAGNOSIS. $P$. cholkei sp.n. is closely related to $P$. longapophysis from China (Yunnan), but can be easily distinguished by the following characters: the minute and sharp embolus pointed to 12 o'clock, resembling tip of an elephant's trunk (Fig. 16; embolus pointed to one o'clock in $P$. longapophysis); the prolateral tegular extension uniformly 


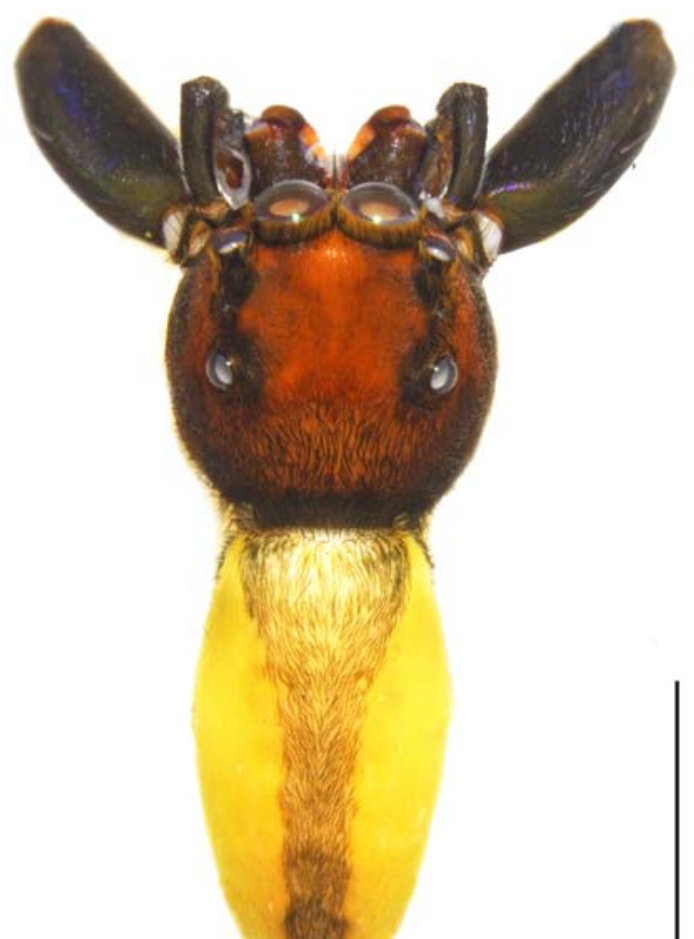

4

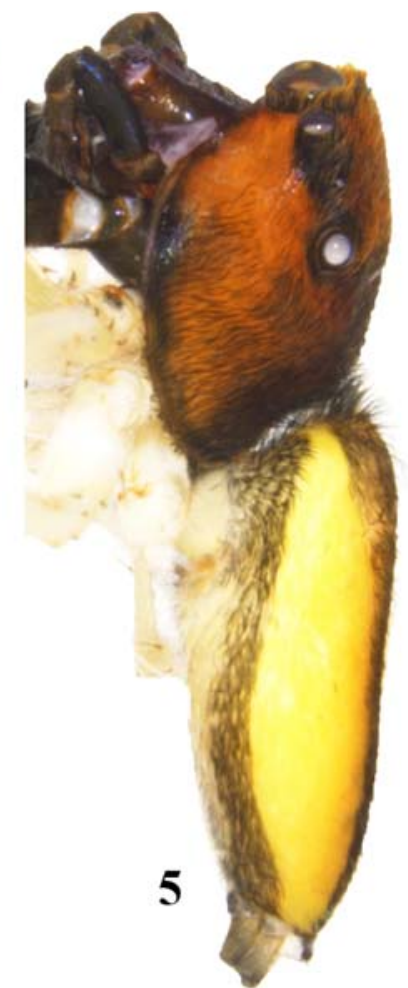

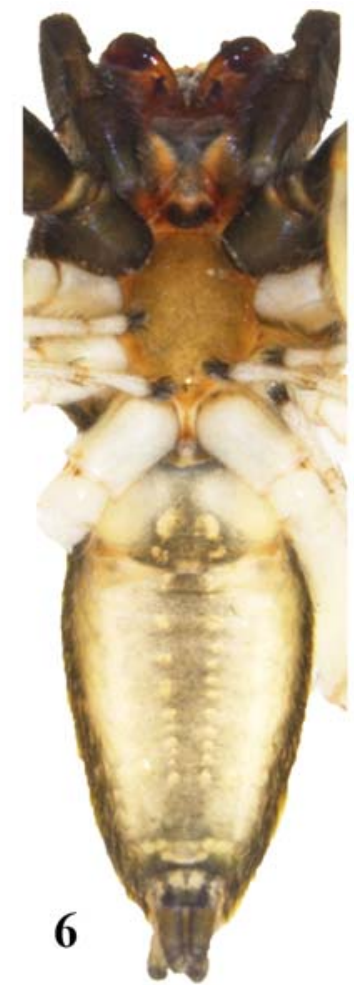

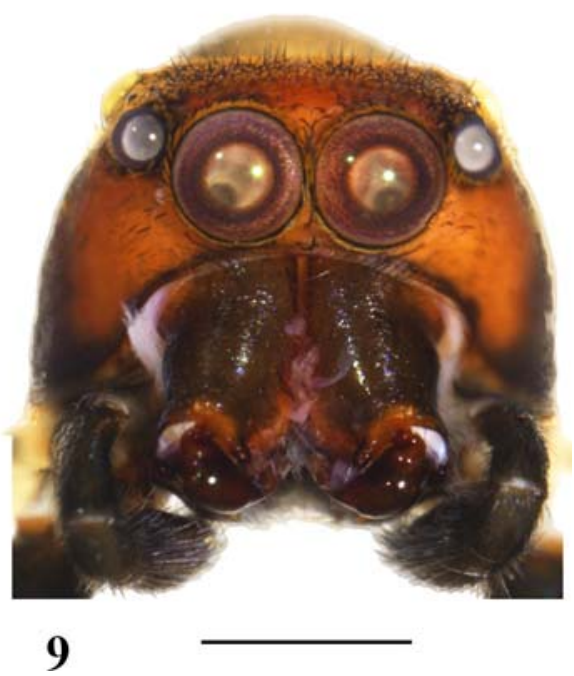

Figs 4-9. Holotype male of Phintella cholkei sp.n.: 4 - body, dorsal view; 5 - same, lateral view; 6 - same, ventral view; 7 - left chelicera, front view; 8 - same, back view; 9 - carapace, front view. Scale bars: $1 \mathrm{~mm}(4-6) ; 0.1 \mathrm{~mm}(7-8) ; 0.5 \mathrm{~mm}(9)$.

Рис. 4-9. Голотип-самец Phintella cholkei sp.n.: 4 - тело, вид сверху; 5 - то же, вид сбоку; 6 - то же, вид снизу; 7 - левая хелицера, вид спереди; 8 - то же, вид сзади; 9 - головогрудь, вид спереди. Масштаб: 1 мм (4-6); 0,1 мм (7-8); 0,5 мм (9).

wide apically (Fig. 16; much broader apically in P. longapophysis); RTA slightly bent at its broad base and slightly curved apically (Figs 16, 17; markedly curved and wavy in P. longapophysis, cf. Fig. 2b in Lei \& Peng [2013]); males with the reddish brown carapace, yellowish abdomen with a median black longitudinal stripe (Figs 4-5; different colour pattern in $P$. longapophysis); the contiguous spermathecae and larger epigynal pockets than those in $P$. longapophysis (Figs 18-19).
DESCRIPTION. MaLe (holotype; Figs 1-2, 4-9). Carapace pear-shaped, reddish brown, with black margins (Figs 4-5). Cephalic region with scattered black setae; eyes encircled by black patched and orange setae; eye rows makes nearly a square shape; thoracic region with numerous black setae (Figs 4-5, 9). Clypeus with long black setae; two stout and long black setae: one in the center of clypeus and second just above the first one (medio-basally to AMEs) (Fig. 9). Endites black, with pale yellow tips (Fig. 6). Chelicerae 

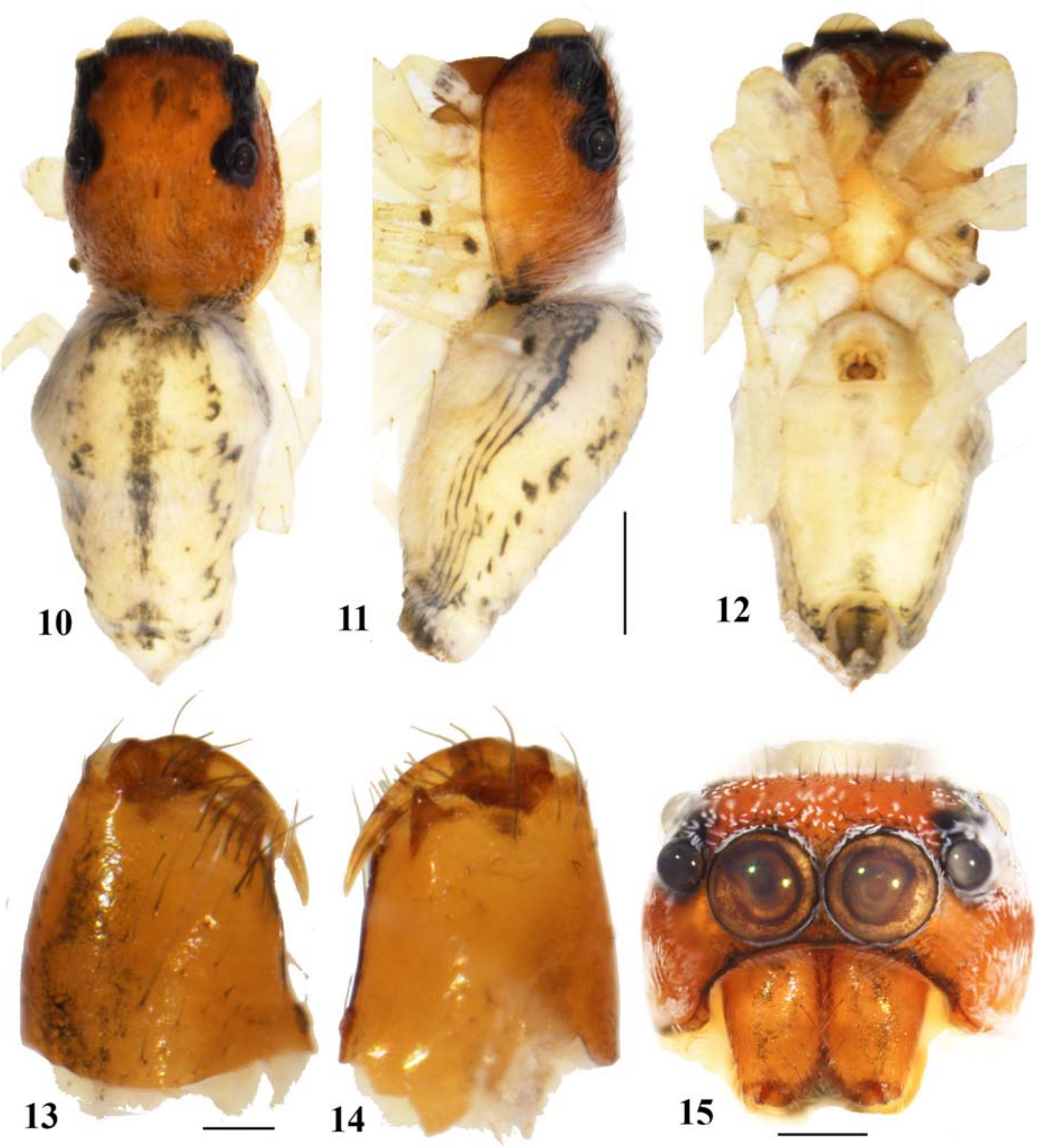

Figs 10-15. Paratype female of Phintella cholkei sp.n.: 10 - body, dorsal view; 11 - same, lateral view; 12 - same, ventral view; 13 left chelicera, front view; 14 - same, back view; 15 - carapace, front view. Scale bars: $0.5 \mathrm{~mm}$ (10-12); $0.1 \mathrm{~mm}(13-14) ; 0.5 \mathrm{~mm}$ (15).

Рис. 10-15. Паратип-самка Phintella cholkei sp.n.: 10 - тело, вид сверху; 11 - то же, вид сбоку; 12 - то же, вид снизу; 13 левая хелицера, вид спереди; 14 - то же, вид сзади; 15 — головогрудь, вид спереди. Масштаб: 0,5 мм (10-12); 0,1 мм (13-14); 0,5 мм (15).

reddish brown to dark brown, with two promarginal and one bigger retromarginal teeth (Figs 7-8). Legs pale yellowish except for coxae and femora of leg I. Abdomen elongated, oval and yellowish dorsally, with a broad grey-brown longitudinal stripe which broadens at its apical end, lateral side with a stripe of black setae (Figs 4-6). Spinnerets dark brown. Body length 2.85. Carapace length 1.14, width 1.13, height 0.77 . Abdomen length 1.51 , width 0.82 , height 0.70 . Eye diameter: ALE 0.15, AME 0.34, PLE 0.17, PME 0.04.
Eye interdistances: AME-AME 0.01, AME-ALE 0.01, ALEALE 0.71, ALE-PME 0.18, PLE-PLE 0.76, PME-PME 0.79 , PME-PLE 0.12. Measurements of palp and legs. Palp $1.04[0.42,0.12,0.11,0.39]$, I $2.58[0.78,0.40,0.61,0.49$, $0.30]$, II $2.01[0.60,0.34,0.48,0.36,0.23]$, III 2.55 [0.77, $0.30,0.57,0.58,0.33]$, IV $2.94[0.95,0.33,0.65,0.67$, $0.34]$. Leg formula: 4132 . Spination: palp: spineless; legs: femora I \& III 1300, II 0400, IV 0310; patellae I-IV 0000; tibiae I 0003, II 0001, III-IV 1020; metatarsi I 0004, II 

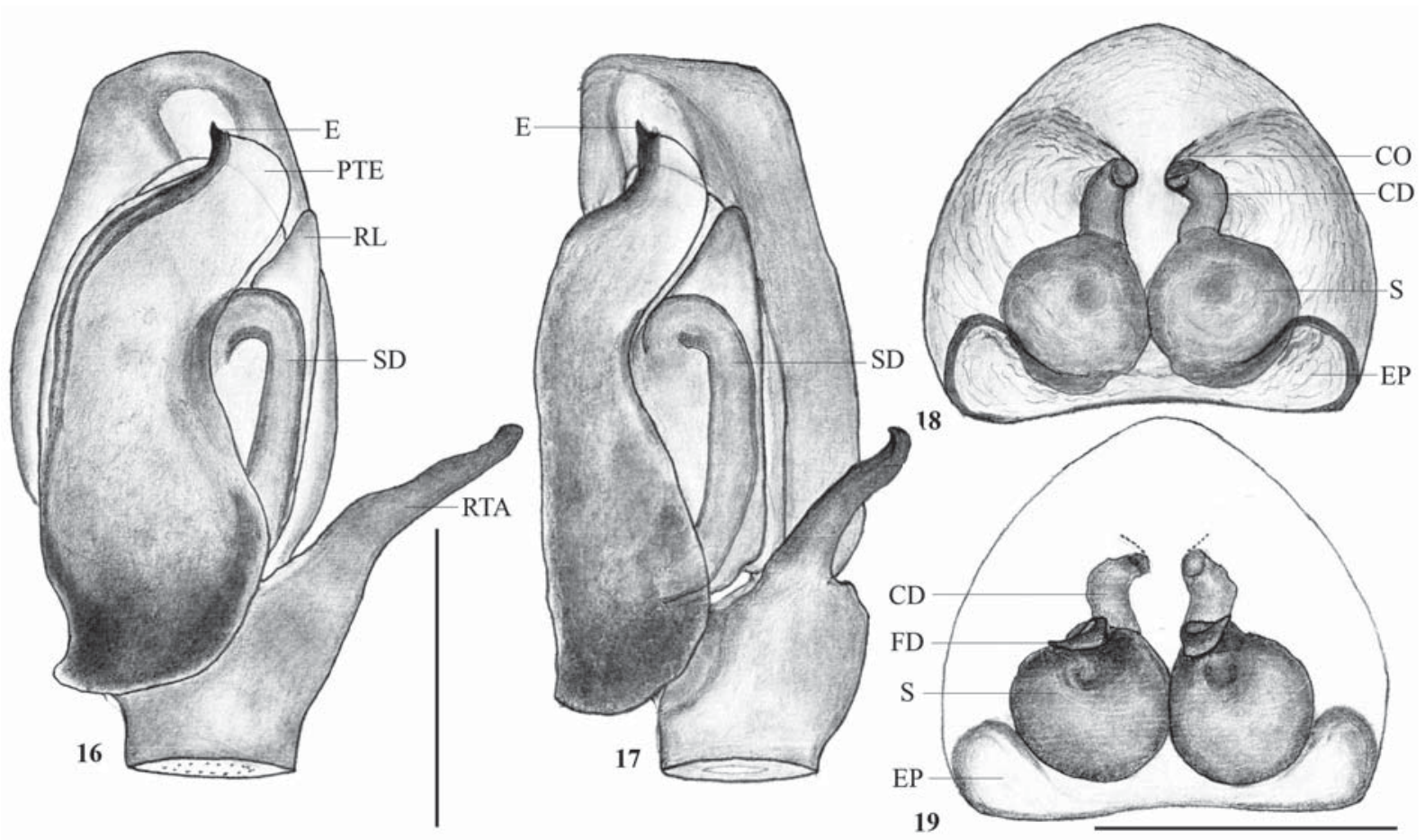

Figs 16-19. Copulatory organs of Phintella cholkei sp.n.: 16 - male left palp, ventral view; 17 - same, retrolateral view; 18 epigyne, ventral view; 19 - vulva, dorsal view. Abbreviations as explained in 'Materials and methods'. Scale bars: 0.2 mm (16-19).

Рис. 16-19. Копулятивные органы Phintella cholkei sp.n.: 16 - левая пальпа самца, вид снизу; 17 — то же, вид сбоку-сзади; 18 эпигина, вид снизу; 19 - вульва, вид сверху. Сокращения как в 'Материалах и методах’. Масштаб: 0,2 мм (16-19).

1010, III 2220; IV 1210; tarsi I-IV 0000. Palp (Figs 16-17): palpal segments dark brown. Tegulum bi-lobed: a larger prolateral lobe with a medio-retrolateral concavity and enlarged disto-prolateral region; a smaller and narrower retrolateral lobe with a noticeable retrolateral inclination (Fig. 16). Embolus minute, pointed to 12 o'clock, complemented by prolateral tegular extension (Fig. 16). Tibia with long RTA, slightly bent at its broad base and curved, pointed tip apically (Figs 16-17).

Female (paratype; Figs 1, 3, 10-15). As described for the male except as follows: cephalic region with a medial black patch in the ocular region, and covered with scattered black and whitish setae; eyes encircled by white setae; thoracic region with longer whitish setae and scattered black setae; endities and legs pale yellow (Figs 10-11, 15). Abdomen oval, pale yellow, dorsally with three dark grey and incomplete longitudinal bands, laterally with black striation (Figs 10-12). Body length 3.83. Carapace length 1.60, width 1.34 , height 0.83 . Abdomen length 2.31, width 1.39, height 1.09. Eye diameter: ALE 0.16, AME 0.39, PLE 0.17, PME 0.05. Eye interdistances: AME-AME 0.01, AME-ALE 0.02, ALE-ALE 0.80, ALE-PME 0.23, PLE-PLE 0.96, PMEPME 0.98, PME-PLE 0.17. Measurements of palp and legs. Palp 1.20 [0.42, 0.17, 0.22, 0.39], I 2.46 [0.77, 0.37, 0.60, $0.43,0.29]$, II $2.22[0.71,0.29,0.54,0.42,0.26]$, III 2.79 $[0.85,0.29,0.62,0.65,0.38]$, IV $3.35[1.13,0.35,0.75$, $0.76,0.36]$. Leg formula: 4312 . Spination. Palp: spineless; legs: femora I-II 0300, III 1400, IV 0400; patellae I-IV 0000; tibiae I 1003, II-III 0001, IV 10002; metatarsi I 0004, II 1002, III-IV 1021; tarsi I-IV 0000. Epigyne (Figs 1819): epigyne with prominent, wide epignal pocket situated at proximal epigynal margin (Fig. 18); spermathecae heavily sclerotized, spherical and contiguous (Fig. 19); copulatory ducts nearly straight except for a slight curve apically (Fig. 19).

OVIPOSITION AND MATERNAL CARE. Nearly twenty five egg sacs of the new species have been observed in the wild, all were guarded by females (Fig. 21). Each egg sac contains pale yellow eggs (colour becomes visibly dark yellow as eggs develop), and egg numbers varied from 8 to 25 depending to the size of the corresponding sacs which varied from $0.6 \mathrm{~cm}$ to $1.0 \mathrm{~cm}$ (Figs 22-23). Females usually make their egg sacs on a leaf underside and rarely on the upper surface; in majority of observations, egg sacs were made on leaves of Millettia pinnata (Linnaeus). Each egg sac consists of two layers of silk protecting eggs, along with a single entrance. Many times egg sacs were accompanied by a retreat in which females resided protecting the eggs until dispersal starts (Figs 21, 25).

HABITAT. The habitat in the type locality along roads and residential buildings is markedly impacted by man. Yet, it has several green patches covered by the vegetation comprising of M. pinnata (dominant), Musa acuminata Cola, Murraya koenigii (Linnaeus), Psidium guajava Linnaeus, along with several grass species. The described spider species seems to mainly feed on the whiteflies, plant-hoppers, wasps and book-lice. It also co-exists with the following spider species: Phintella vitata (C.L. Koch, 1846), Icius spp., Telamonia spp., Rhene sp., Marengo sp., Oxyopes spp.

The specimens observed in the Aarey Milk Colony were found under tree leaves at approximately 2-7 feet above the ground. The region is dominated by trees with thick canopies. During the survey, six females were observed in their retreats along with their egg sacs and on four occasions, males 

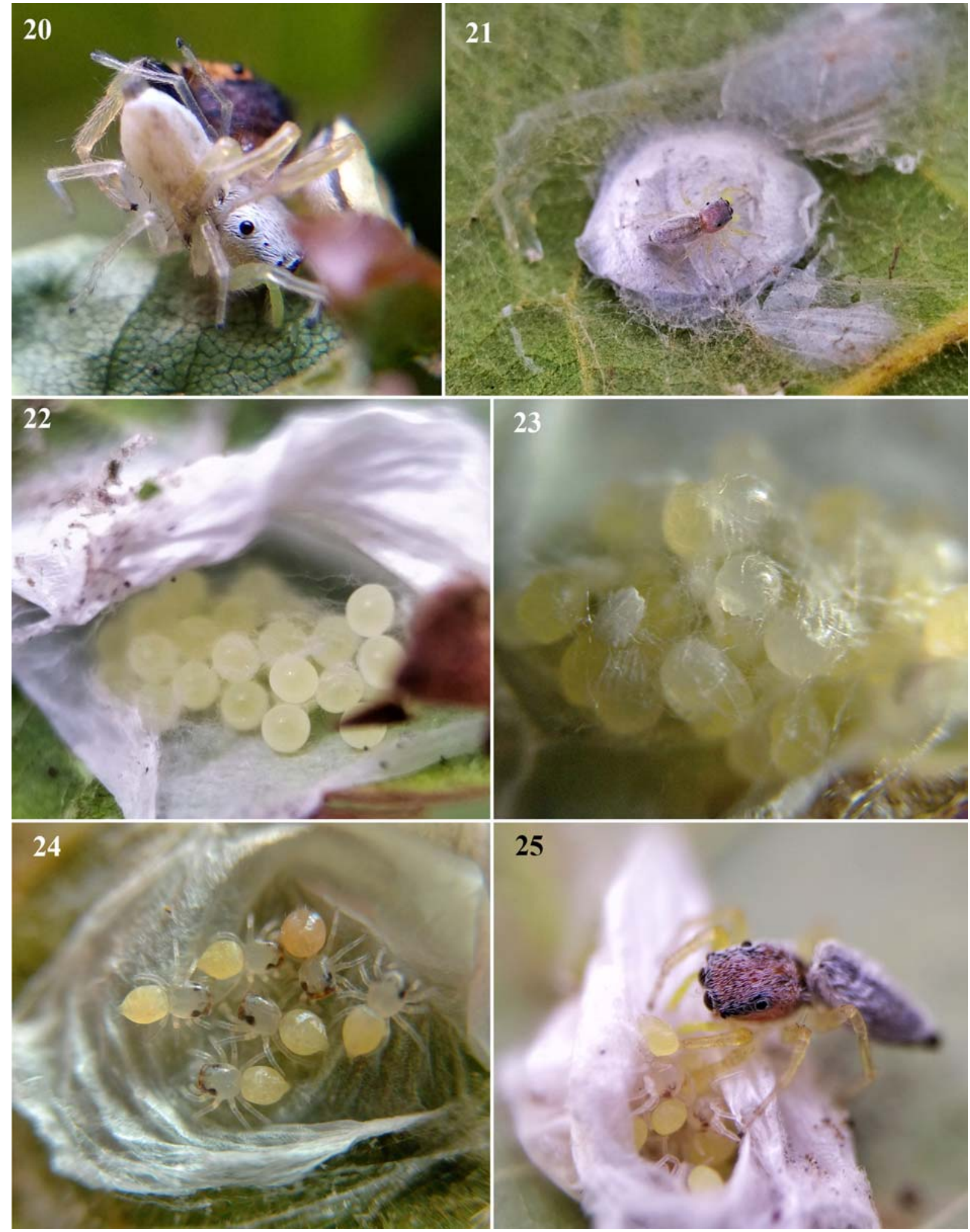

25

Figs 20-25. Phintella cholkei sp.n.: 20 - mating; 21 - female guarding its egg sac; 22 - eggs in the initial stage of development; 23 colour changes in developing eggs; 24 - newly hatched spiderlings; 25 - female protecting newly hatched spiderlings.

Pис. 20-25. Phintella cholkei sp.n.: 20 - копуляция; 21 - самка охраняющая свой кокон; 22 - яйца в начальной стадии развития; 23 - цветовые изменения в развивающихся яйцах; 24 - свежевылупившиеся личинки; 25 - самка охраняющая свежевылупившихся личинок. 

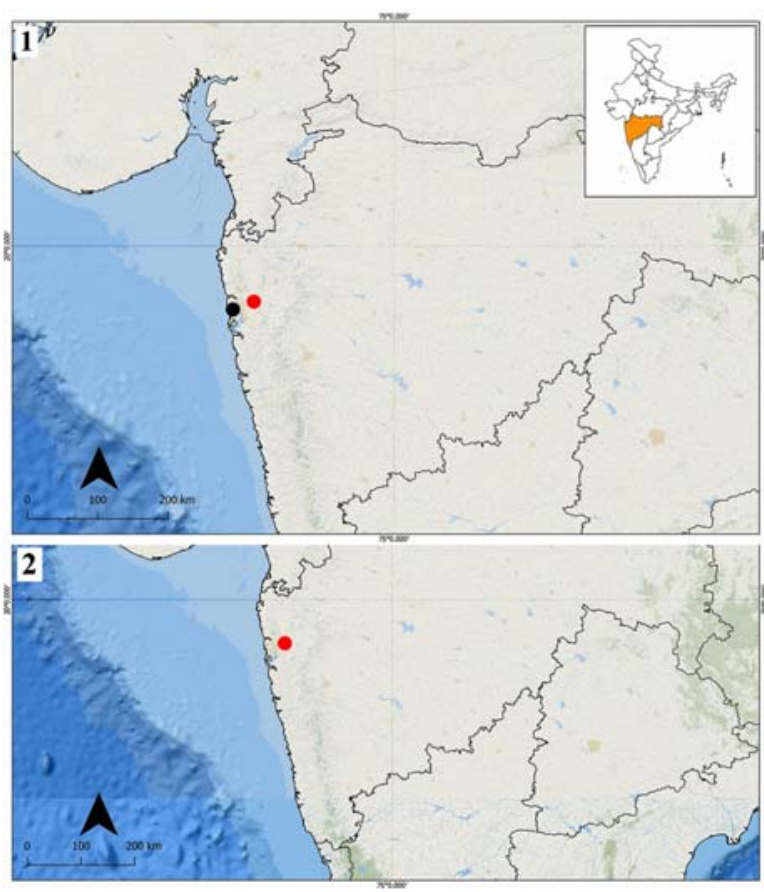

Maps 1-2. Collecting localities of Phintella cholkei sp.n. (1) and Icius tukarami sp.n. (2); red circles show the type localities.

Карты 1-2. Точки находок Phintella cholkei sp.n. (1) и Icius tukarami sp.n. (2); красные кружки показывают типовые локалитеты.

were found around female retreats. Some individuals were also observed near human settlement. The majority of adult males and females were observed during the monsoon.

DISTRIBUTION. India: Maharashtra (Map 1).

\section{Icius Simon, 1876}

Type species: Icius hamatus (C.L. Koch, 1846).

DIAGNOSIS. Icius can be easily distinguished from other chrysillni genera by the following combination of characters: the presence of stridulatory organ consisting of a femoral row of setae with stout base and lateral carapace sides with fine rugose surface; the tegulum with a welldeveloped posterior region; the embolus small to moderate, arising from the apico-prolateral region of tegulum (except for I. peculiaris Wesołowska et Tomasiewicz, 2008 in which the embolus arises from its disto-prolateral region); sometimes the tegulum with an apical extension; RTA small to large, simple or modified (= furcated); the spermathecae spherical to elongate, oval or tubular, situated transversely or longitudinally; the copulatory ducts situated longitudinally, simple or coiled (in Indian species), with or without accessory glands. For detailed diagnostic features and description of the genus see Alicata \& Cantarella [1994].

\section{Icius tukarami Prajapati, Kumbhar et Kamboj sp.n. Figs 26-36, Map 2.}

TYPE. Holotype $\sigma^{7}$ (GEER, 97244A), India, Maharashtra, Thane, Rambaug in Kalyan $\left(19^{\circ} 14^{\prime} 28.44^{\prime \prime} \mathrm{N}, 73^{\circ} 8^{\prime} 9.71^{\prime \prime} \mathrm{E}\right), 12 \mathrm{~m}$ a.s.1., hand-collected from foliage, 13.07.2020, S.B. Kumbhar.

ETYMOLOGY. The specific epithet is dedicated to a hero of the 26/11 Mumbai terror attack, ASI Tukaram Omble AC, who took 23 bullets and captured the terrorist of the attack.
DIAGNOSIS. I. tukarami sp.n. is similar to I. kumariae Caleb, 2017, but can be easily distinguished by the longer and wavy embolus (Fig. 34), the presence of two RTAs, of which one is broad, tridentate and possesses a significant median dent (Figs 35-36), and the unique body colour pattern (Figs 28-29).

DESCRIPTION. MALE (Figs 26-33). Carapace flattened, rectangular in shape, with thin white margins; cephalic region black, covered with pale yellow setae, small patch of whitish hairs above PLEs and other scattered whitish hairs covering margins of eye field, several stout black setae situated behind and above ALEs; thoracic region with two longitudinal whitish stripes (Figs 28-29, 33). Endites dark brown (Fig. 30). Chelicerae dark brown, with two promarginal and one retromarginal teeth (Figs 32-33). Legs pale yellow except for brownish leg I with five apico-prolateral setae having stout bases (Fig. 31). Abdomen elongated and yellowish brown, with two longitudinal thin white stripes and dark apico-medial chevron-shaped mark; abdominal margins dark brownish, with white striation (Figs 28-29). Spinnerets brownish (Fig. 30). Body length 3.23. Carapace length 1.45, width 0.97 , height 0.49 . Abdomen length 1.78 , width 0.72 , height 0.64. Eye diameter: ALE 0.13, AME 0.28, PLE 0.13, PME 0.02. Eye interdistances: AME-AME 0.01, AMEALE 0.01, ALE-ALE 0.60, ALE-PME 0.23, PLE-PLE 0.71, PME-PME 0.74, PME-PLE 0.17. Measurements of palp and legs. Palp $0.94[0.39,0.07,0.12,0.36]$, I 2.34 [0.72, $0.45,0.56,0.37,0.24]$, II $1.66[0.52,0.29,0.40,0.26,0.19]$, III $1.68[0.52,0.24,0.32,0.33,0.27]$, IV $2.33[0.74,0.33$, $0.55,0.42,0.29]$. Leg formula: 4132 . Spination. Palp: spineless; legs: femora I 0404, II \& IV 0400, III 0500; patellae IIV 0000; tibiae I 0030, II-III 0001, IV 0002; metatarsi I 0004, II 1002, III-IV 1021; tarsi I-IV 0000. Palp (Figs 3436): palpal segments brownish. Embolus stout, longer, wavy and with a narrowed tip pointed to one o'clock (Fig. 34). There are two RTAs: the first superior, with a broad base, tridentate (with a significant median dent); and the second inferior, simple, triangular, with a sharp tip (Figs 35-36).

FEMALE. Unknown.

DISTRIBUTION. India: Maharashtra (Map 2).

\section{Discussion}

Phintella comprises a total of 12 Indian representatives [Prószyński, 1992a,b; WSC, 2021]: P. accentifera (Simon, 1901), P. assamica Prószyński, 1992, P. bifurcata Prószyński, 1992, P. coonooriensis Prószyński, 1992, P. debilis (Thorell, 1891), P. indica (Simon, 1901), P. macrops (Simon, 1901), P. nilgirica Prószyński, 1992, P. reinhardti (Thorell, 1891), P. suknana Prószyński, 1992, P. vittata (C.L. Koch, 1846) and $P$. cholkei sp.n. Of them, P. assamica, P. nilgirica, $P$. reinhardti and $P$. suknana remain known from the females only, whereas $P$. indica and $P$. macrops from the males. The remaining Indian Phintella species are known from both sexes. Except for $P$. cholkei sp.n., all other Indian Phintella are distributed in the eastern or southern regions of India. Two species, $P$. coonooriensis and $P$. nilgirica, shares their type localities in Coonoor, Tamil Nadu [Prószyński, 1992b], mentioned by the latter author as a garden in Coonoor for both species. Since $P$. nilgirica is known from the female and strongly resembles that of $P$. coonooriensis (cf. Figs 46-53, 60-63 in Prószyński [1992b]), it is quite 

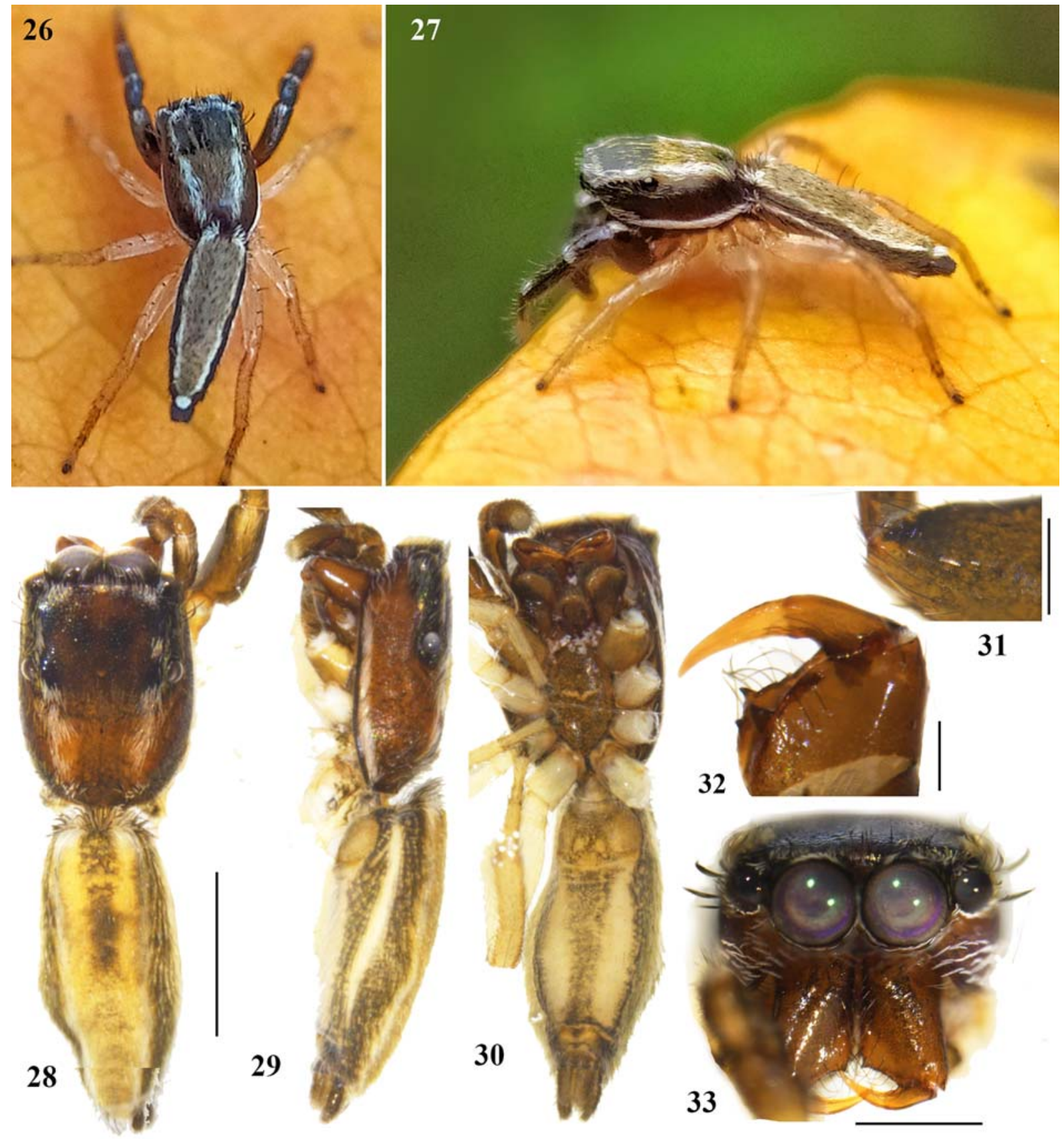

Figs 26-33. Holotype male of Icius tukarami sp.n.: 26-27 — live specimen; 28 - body, dorsal view; 29 — same, lateral view; 30 same, ventral view; 31 - left femur I, apico-prolateral view; 32 - left chelicera, back view; 33 - carapace, frontal view. Scale bars: 1 $\mathrm{mm}(28-30) ; 0.1 \mathrm{~mm}(31-33)$.

Рис. 26-33. Голотип-самец Icius tukarami sp.n.: 26-27 - живой экземпляр; 28 - тело, вид сверху; 29 - то же, вид сбоку; $30-$ то же, вид снизу; 31 - левое бедро I, вид апико-пролатерально; 32 - левая хелицера, вид сзади; 33 — головогрудь, вид спереди. Масштаб: 1 мм (28-30); 0,1 мм (31-33).

possible that both names are synonymous. Yet, Żabka [1988] questioned the validity of $P$. reinhardti, of which epigyne strongly resembles that of $P$. debilis (cf. Figs. 120-121 in Żabka [1988]), and hence the former species name could be a junior synonym of the latter. However, both assumptions can be confirmed by a reexamination of the corresponding types only. Finally,
$P$. indica and $P$. suknana remain poorly described species and are in need of better descriptions.

The genus Icius was only recently found in India, with four species being described to date: I. alboterminus (Caleb, 2014), I. kumariae, I. vikrambatrai Prajapati, Malamel, Sudhikumar et Sebastian, 2018 and $I$. tukarami sp.n. Except for the new species, all Icius 


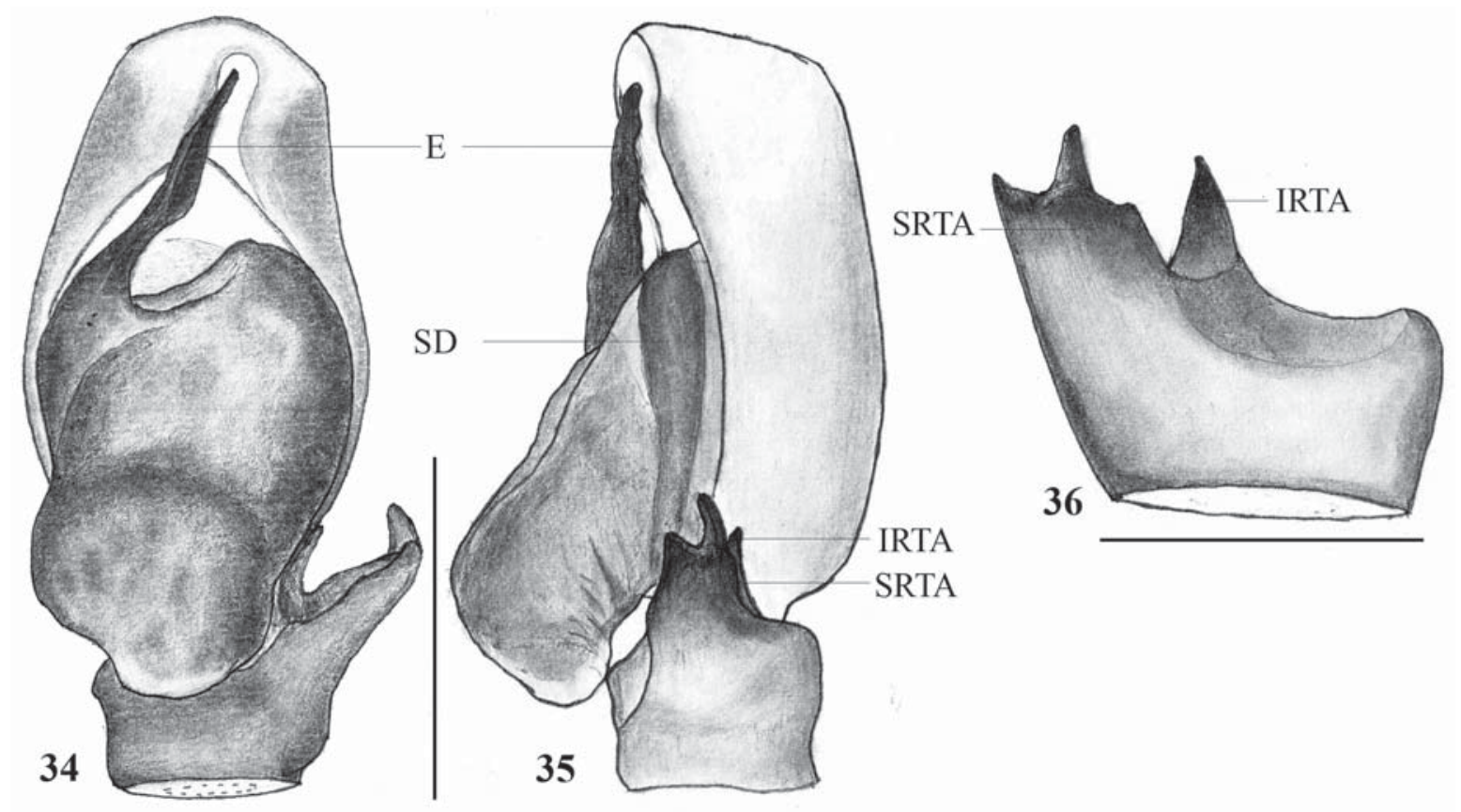

Figs 34-36. Left male palp of the holotype of Icius tukarami sp.n.: 34 - ventral view; 35 - retrolateral view; 36 - palp tibia, dorsal view. Abbreviations as explained in 'Materials and methods'. Scale bars: $0.2 \mathrm{~mm}(34,35) ; 0.1 \mathrm{~mm}(36)$.

Рис. 34-36. Левая пальпа голотипа-самца Icius tukarami sp.n.: 34 - вид снизу; 35 - вид спереди-сбоку; 36 - голень пальпы, вид сверху. Сокращения как в 'Материалах и методах'. Масштаб: 0,2 мм (34, 35); 0,1 мм (36).

species are known from both sexes. The present discovery of another unknown species from India indicates that the diversity of Indian Icius seems to be much higher than currently known.

Acknowledgements. DP is grateful to Dr Ketan Tatu, Senior Scientist, GEER Foundation for his support throughout the research period. The authors wish to thank Dr Vijay Makwana, Laboratory superintendent, GEER Foundation for giving access to laboratory facilities. We are also thankful to Miss Priyal Prajapati for her generous help in preparation of figure plates. The help of Miss Maitry Jani with the preparation of distribution maps is sincerely acknowledged. RS \& JC thank Dr Krushnamegh Kunte, NCBS, Bengaluru for his help with depositing the types in the collection facility. We extend our thanks to Dr Dmitri Logunov (Manchester, UK) for providing valuable suggestions, editing the manuscript and figure plates.

\section{References}

Alicata P., Cantarella T. 1994. The Euro-mediterranean species of Icius (Araneae, Salticidae): a critical revision and description of two new species // Animalia. Vol.20. P.111-131.

Caleb J.T.D. 2017. Jumping spiders of the genus Icius Simon, 1876 (Araneae: Salticidae) from India, with a description of a new species // Arthropoda Selecta. Vol.26. No.4. P.323-327.

Davies V.T. 1994. The huntsman spiders Heteropoda Latreille and Yiinthi gen. nov. (Araneae: Heteropodidae) in Australia // Memoirs of the Queensland Museum. Vol.35. P.75-122.

Lei H., Peng X.J. 2013. Five new species of the genus Phintella (Araneae: Salticidae) from China // Oriental Insects. Vol.47. P.99-110.

Maddison W.P. 2015. A phylogenetic classification of jumping spiders (Araneae: Salticidae) // Journal of Arachnology. Vol.43. P.231-292.
Prajapati D.A., Kamboj R.D. 2020. Additional morphological notes on the male of Icius alboterminus (Caleb, 2014) (Aranei: Salticidae) with new distribution records from India // Journal of Threatened Taxa. Vol.12. No.4. P.15475-15480.

Prajapati D.A., Malamel J.J., Sudhikumar A.V., Sebastian P.A. 2018. A new species of the jumping spider genus Icius Simon, 1876 from India (Aranei: Salticidae: Chrysillini) // Arthropoda Selecta. Vol.27. No.4. P.330-334.

Prószyński J. 1984. Atlas rysunków diagnostycznych mniej znanych Salticidae (Araneae) // Zeszyty Naukowe Wyższej Szkoły Rolniczo-Pedagogicznej w Siedlcach. Vol.2. P.1-177.

Prószyński J. 1978. Distributional patterns of the Palaearctic Salticidae (Araneae) // Symposia of the Zoological Society of London. Vol.42. P.335-343.

Prószyński J. 1992a. Salticidae (Araneae) of the Old World and Pacific Islands in several US collections // Annales Zoologici, Warszawa. Vol.44. P.87-163.

Prószyński J. 1992b. Salticidae (Araneae) of India in the collection of the Hungarian National Natural History Museum in Budapest // Annales Zoologici, Warszawa. Vol.44. P.165-277.

Sebastian P.A., Sankaran P.M., Malamel J.J., Joseph M.M. 2015. Description of new species of Stenaelurillus Simon, 1886 from the Western Ghats of India with the redescription of Stenaelurillus lesserti Reimoser, 1934 and notes on mating plug in the genus (Arachnida, Araneae, Salticidae) // ZooKeys. Vol.491. P.63-78.

WSC 2021. World Spider Catalog (version 21.5) Bern: Natural History Museum Bern; online at: http://wsc.nmbe.ch (accessed on 7 Jan 2020).

Żabka M. 1988. Salticidae (Araneae) of Oriental, Australian and Pacific regions, III // Annales Zoologici, Warszawa. Vol.41. P. 421-479.

Żabka M. 2012. Phlegra Simon, 1876, Phintella Strand 1906 and Yamangalea Maddison, 2009 (Arachnida: Araneae: Salticidae) - new species and new generic records for Australia // Zootaxa. Vol.3176. P.61-68.

Responsible editor D.V. Logunov 